\title{
ESENSI TENGGANG WAKTU SIDANG IKRAR TALAK DI PENGADILAN AGAMA BUKITTINGGI
}

\author{
Rahmiati \\ Institut Agama Islam Negeri Bukittinggi,rabmiati3011@gmail.com \\ Elfiani \\ Institut Agama Islam Negeri Bukittinggi, elfianirais2@gmail.com
}

Diterima: 24 November $2020 \quad$ Direvisi: 16 Desember $2020 \quad$ Diterbitkan: 31 Desember 2020

\author{
(ब) (1) (-) \\ (C)2020 by the authors. Submitted for possible open access publication under the terms and conditions \\ of the Creative Commons Attribution (CC-BY-SA) license (https://creativecommons.org/licenses/by-sa/4.0/) \\ do: DOI : $10.30983 /$ alhurriyah.v5i2.3295
}

\begin{abstract}
This research is motivated by the decree in article 70 of Law act. 7 of 1989 regarding of the Religious Courts which regulates a grace period of 6 (six) months for witnessing a divorce pledge trial at the Religious Court. of setting this rule. The purpose of this study is to determine the implementation of the talak pledge trial at the Bukittinggi Religious Court as well as to know the wisdom of determining the 6 (six) month grace period for pronouncing the divorce vows by the busband against the wife in front of the Religious Court. This paper uses descriptive field research methods within the framework of qualitative analysis from data sources of observation, interviews and literature. The results of research and analysis found that the implementation of the pledge trial at the Bukittinggi Religious Court was carried out after the decision on the divorce divorce case had permanent legal force (inkracht), that is, if there was no ordinary legal remedy against the verdict. The time limit given to carry out the divorce pledge at the trial after the verdict with incrabt is six months after the date of the divorce pledge trial is determined. The wisdom from determining a grace period of 6 (six) months for the busband to pledge his divorce is; First, to give the busband the opportunity to think about reviewing the decision to divorce his wife. Second, protection of the rights of women (wives). In this case, the busband is given the opportunity within this grace period to fulfill the rights of the wife who is demanded in court and decided by the panel of judges.
\end{abstract}

Keywords: Essention, Grace Periode, Divorce Pledge, Religious Court.

\begin{abstract}
Abstrak
Penelitian ini dilatarbelakangi oleb ketentuan dalam Pasal 70 UU No 7 Tabun 1989 tentang Peradilan Agama yang mengatur tenggang waktu 6 (enam) bulan untuk penyaksian sidang ikerar talak di Pengadilan Agama. Aturan ini sejatinya tidak ditemukan di dalam kajian figh, namun secara fungsi belum terungkap kegunaan dari penetapan aturan ini. Tujuan penelitian ini adalah untuk mengetabui pelaksanaan sidang ikrar talak di Pengadilan Agama Bukittinggi sekaligus mengetahui bikmah dari penetapan tenggang waktu 6 (enam) bulan untuk pengucapan ikrar talak oleb suami terbadap isteri dibadapan sidang Pengadilan Agama. Tulisan ini menggunakan metode penelitian lapangan yang bersifat deskriptif dalam kerangka analisis kualitatif dari sumber data observasi, wawancara dan literatur. Hasil penelitian dan analisa ditemukan bahwa pelaksanaan sidang ikrar talak di Pengadilan Agama Bukittinggi dilakukan setelah keputusan perkara cerai talak mempunyai kekuatan bukum tetap (inkracht), yaitu apabila terbadap putusan tersebut tidak adalagi upaya bukum biasa. Tenggang waktu yang diberikan untuk melaksanakan ikrar talak di Persidangan setelah putusan Berkekuatan Hukum Tetap (BHT) adalah enam bulan sejak penetapan hari sidang ikrar talak. Hikmah dari penetapan tenggang waktu 6 (enam) bulan bagi suami untuk mengikrarkan talaknya adalab; Pertama, untuk memberikan kesempatan berpikir kepada suami guna mengkaji ulang keputusan menceraikan isterinya. Kedua, Perlindungan terbadap bak-bak perempuan
\end{abstract}


(isteri). Dalam hal ini, suami diberi kesempatan dalam tenggang waktu tersebut, untuk memenubi bak-bak isteri yang dituntut di persidangan dan diputuskan oleh majelis hakim. Tujuan utama dari ketentuan tenggang waktu untuk ikrar talak adalah untuk. mempersulit terjadinya perceraian dan kemaslahatan terbadap suami (pemohon) dan isteri (termohon).

Kata Kunci: Esensi, Tenggang Waktu, Ikrar Talak, Pengadilan Agama.

\section{PENDAHULUAN}

Pernikahan atau perkawinan merupakan pertalian yang sah antara seorang laki-laki dengan seorang perempuan untuk waktu yang lama. Hal ini sesuai dengan tujuan perkawinan menurut Undang-Undang Nomor 1 Tahun 1974 salah satu "Perkawinan adalah ikatan lahir bathin antara seorang pria dengan seorang wanita sebagai suami isteri dengan tujuan membentuk keluarga (Rumah Tangga) yang bahagia dan kekal berdasarkan Ketuhanan Yang Maha Esa". Oleh karena itu perkawinan dalam ajaran Islam mempunyai nilai ibadah sebagaimana yang ditegaskan dalam Kompilasi Hukum Islam Pasal 2 menegaskan bahwa "perkawinan adalah akad yang sangat kuat (mitsaqan ghalidzan) untuk menaati perintah Allah, dan melaksanakannya merupakan ibadah."

Akan tetapi, hubungan lahir itu ada kemungkinan tidak dapat kekal, terganggu, bahkan dapat putus dengan berbagai alasan, maka ajaran Islam membolehkan untuk melakukan perceraian atau talak sekalipun sangat dimurkai Allah SWT. ${ }^{1}$ sesuai dengan sabda Rasulullah S.A.W yang artinya :

"Dari Ibn Umar R.A bersabda: Perbuatan yang halal yang paling dibenci Allah S.W.T adalah talak." Diriwayatkan oleh Ibnu Majah. ${ }^{2}$

1 Musda Asmara dan Reti Andira, "Urgensi Talak di Depan Sidang Pengadilan Perspektif Maslahah Mursalah." Al-Istinbath: Jurnal Hukum Islam 3, no.2 (2018): 208.

2 Muhammad bin Ismail Al-Kahlani, Subulus Salam Syarah Bulughul Maram (Jakarta Timur : Darus Sunnah Press, 1926), Jilid III, 168.
Dalam ajaran Islam, pelaksanaan talak disaksikan oleh dua orang saksi yang adil diantara kamu (Q.S At-Talaq : 2). Selanjutnya, hukum perkawinan di Indonesia juga mengatur tentang tata cara perceraian atau talak yang disaksikan didepan sidang Pengadilan Agama. ${ }^{3}$ Hal ini berdasarkan UndangUndang No 1 tahun 1974 Pasal 39 ayat (1) bahwa "Perceraian hanya dapat dilakukan didepan sidang pengadilan setelah pengadilan yang bersangkutan berusaha dan tidak berhasil mendamaikan kedua belah pihak". Hal yang sama juga diatur dalam UndangUndang nomor 7 tahun 1989 Pasal 65 dan dalam Kompilasi Hukum Islam Pasal 115. Khusus bagi yang beragama Islam dibedakan antara cerai talak dengan cerai gugat.

Prosedur perceraian dalam hal cerai talak adalah dengan pengajuan permohonan cerai talak oleh suami ke Pengadilan Agama. Hal ini sebagaimana diatur dalam pasal 66 Undang-Undang Peradilan Agama tahun 1989 (selanjutnya disebut UUPA), yang berbunyi :

1. Seorang suami yang beragama Islam yang akan menceraikan isterinya mengajukan permohonan kepada Pengadilan untuk mengadakan sidang guna menyaksikan ikrar talak.

2. Permohonan sebagaimana yang dimaksud dalam ayat (1) diajukan kepada pengadilan yang daerah

3 H. Abustam, "Pelaksanaan Ikrar Talak di Hadapan Sidang Pengadilan Agama (Suatu Tinjauan Filsafat Hukum Islam)." Al-Risalah: Jurnal Hukum Keluarga Islam 2, no. 2 (2016): 161. 
hukumnya meliputi tempat kediaman termohon, kecuali apabila termohon dengan sengaja meninggalkan tempat tinggal bersama tanpa izin pemohon.

Berdasarkan permohonan ini, pengadilan akan memeriksa, mengadili dan memutuskan perkara tersebut. Hal ini diatur dalam Pasal Pasal 70 UUPA sebagai berikut:

1. Pengadilan setelah berkesimpulan bahwa kedua belah pihak tidak mungkin lagi didamaikan dan telah cukup alasan perceraian, maka pengadilan menetapkan bahwa permohonan tersebut dikabulkan.

2. Terhadap penetapan sebagaimana yang dimaksud dalam ayat (1), isteri dapat mengajukan banding.

3. Setelah penetapan tersebut memperoleh kekuatan hukum tetap, pengadilan menentukan hari sidang penyaksian ikrar talak, dengan memanggil suami dan isteri atau wakilnya untuk menghadiri sidang tersebut.

4. Dalam sidang itu suami atau wakil yang diberi kuasa khusus dalam suatu akta otentik untuk mengucapkan ikrar talak yang dihadiri oleh isteri atau kuasanya.

5. Jika isteri telah mendapat panggilan setelah sah atau patut, tetapi tidak datang sendiri atau tidak mengirim wakilnya maka suami atau wakilnya dapat mengucapkan ikrar talak tanpa hadirnya isteri atau wakilnya.

6. Jika suami dalam tenggang waktu 6 (enam) bulan sejak ditetapkan hari sidang penyaksian ikrar talak, tidak datang menghadap sendiri atau tidak mengirim wakilnya, meskipun telah mendapat panggilan secara sah atau patut, maka gugurlah kekuatan penetapan tersebut dalam perceraian tidak dapat diajukan lagi berdasarkan lasan yang sama.

Sehubungan dengan bunyi Pasal 70 ayat (6) UUPA, didalam KHI pasal 131 ayat (4) juga dinyatakan bahwa bila suami tidak mengucapkan ikrar talak dalam tempo 6 (enam) bulan terhitung sejak putusan Pengadilan Agama tentang izin ikrar talak baginya mempunyai kekuatan hukum yang tetap, maka hak suami untuk mengikrarkan talak gugur dan ikatan perkawinan tetap utuh.

Berdasarkan Undang-Undang nomor (7) tahun 1989 Pasal 70 ayat (6) dan KHI Pasal 131 ayat (4) diatas membuktikan bahwa tidak dikatakan perceraian dan berpisahnya antara suami isteri kecuali perceraian dilakukan dan disaksikan di depan sidang Pengadilan Agama. Dalam hal ini hak talak bagi suami untuk mengucapkan ikrar talak di Pengadilan Agama seakan-akan dihalangi oleh Undang-Undang dan KHI, dan secara tidak langsung menghilangkan hak prerogatif suami untuk mentalak isteri ketika kerukunan dan keharmonisan rumah tangganya tidak bisa dipertahankan lagi dengan berbagai upaya. Padahal dalam syariat Islam ada hak bagi suami untuk menjatuhkan talak kepada isterinya dengan tanpa adanya batasan waktu.

Berdasarkan latar belakang masalah yang telah diuraikan di atas, peneliti membatasi pembahasan dalam penelitian ini dengan rumusan masalah; bagaimana pelaksanaan ikrar talak di Pengadilan Agama Bukittinggi?, dan mengapa ditentukan tenggang waktu 6 (enam) bulan bagi suami untuk mengucapkan ikrar talak?

Berdasarkan permasalahan yang dimukakan diatas, maka tujuan dari penelitian adalah; untuk mengetahui pelaksanana ikrar talak di Pengadilan 
Agama, dan untuk mengetahui hikmah penetapan tenggang waktu 6 (enam) bulan bagi suami untuk mengucapkan ikrar talak. Sedangkan kegunaan dari penelitian ini adalah untuk berkontribusi, baik dalam wilayah akademis maupun wilayah sosial. Pada bidang akademis, penelitian ini diharapkan dapat memperkaya literatur tentang Hukum Keluarga khususnya tentang Ikrar Talak dalam perceraian, serta memperluas wawasan peneliti terkait dengan ketentuan tentang ikrar talak. Sedangkan dalam aspek sosial, hasil penelitian ini diharapkan memberi kontribusi positif bagi masyarakat dalam memahami dengan baik tentang perceraian khusus cerai talak dengan segala akibat hukumnya. Hal ini diharapkan dapat pula menekan angka perceraian.

Penelitian ini menggunakan metode deskriptif dengan pendekatan kualitatif. Alasan menggunakan metode deskriptif ini adalah untuk dapat menggambarkan sifat-sifat individu, keadaan, dan situasi kehidupan sosial budaya. Hal ini sesuai dengan pendapat Selitz yang menyatakan bahwa, penelitian deskriptif mencoba menggambarkan tentang sifat-sifat individu, keadaan, gejala-gejala dalam kelompok tertentu, menentukan adanya hubungan tertentu antara satu gejala dengan gejala lainnya dalam masyarakat. Sugiyono mengemukakan bahwa "metode deskriptif adalah suatu metode yang berfungsi untuk mendeskripsikan atau memberi gambaran terhadap objek yang diteliti, melalui data atau sampel yang telah terkumpul sebagaimana adanya, tanpa melakukan analisis dan membuat kesimpulan yang berlaku untuk umum".
Dengan demikian metode deskriptif memusatkan perhatian kepada masalah-masalah sebagaimana adanya saat penelitian dilaksanakan. Selanjutnya hasil penelitian diolah dan dianalisis untuk mendapatkan kesimpulan. Dalam hal ini, objek yang diteliti dan akan dideskripsikan adalah tentang pelaksanaan sidang ikrar talak di Pengadilan Agama Bukittinggi.

Selanjutnya pendekatan kualitatif yaitu suatu pendekatan yang berguna untuk mempelajari fenomena sosial keagamaan dengan tujuan menjelaskan dan menganalisis perilaku manusia dan kelompok dari sudut pandang yang sama sebagaimana objek yang diteliti melihat masalah tersebut. Menurut Bogdan dan Taylor dalam Lexy J. Moleong, penelitian kualitatif merupakan prosedur penelitian yang menghasilkan data deskriptif berdasarkan pengamatan dalam berbagai situasi sosial, atau agama masyarakat berupa kata-kata tertulis dan tak tertulis dari perilaku orang yang diamati. $^{4}$

Pendekatan kualitatif digunakan dalam penelitian ini dengan alasan, pertama objek yang akan diteliti adalah keadaan atau gejala sosial dalam kelompok tertentu, yaitu orang-orang yang melakukan perceraian di hadapan pengadilan. Kedua penelitian ini berusaha untuk memahami konteks perilaku dalam kelompok tertentu, dalam hal ini tentang penelitian dengan pendekatan kualitatif lebih leluasa menemukan hal-hal yang unik, karena menempatkan objek sebagaimana adanya, menjadi pelaku kreatif dan dinamis.

Sumber data yang digunakan dalam penelitian ini adalah: (1) Data

${ }^{4}$ Lexy J. Moleong, Metode Penelitian Kualitatif (Bandung : PT. Remaja Rosda Karya 1997), 4. 
primer, yakni data yang diperoleh secara langsung dari lapangan yang didapatkan dari informan penelitian. Dalam penelitian ini, data primer dikumpulkan melalui wawancara dan observasi. (2) Data sekunder, yakni data yang didapatkan dari studi kepustakaan, berupa buku-buku yang berhubungan dengan hukum perkawinan, peraturan perundang-undangan, serta dokumen dan sumber-sumber lain yang berkaitan dengan permasalahan yang dibahas dan mendukung untuk penyusunan laporan penelitian ini.

Teknik pengumpulan data dalam penelitian ini adalah melalui; (1) Wawancara adalah cara untuk mendapatkan informasi dengan cara berkomunikasi secara langsung pada informan untuk mendapatkan informasi mengenai objek yang diteliti. Lexy J. Moleong menjelaskan bahwa wawancara dilakukan dengan mengkonstruksi mengenai orang, kejadian, kegiatan, organisasi, perasaan, motivasi, tuntutan, kepedulian dan lain-lain. ${ }^{5}$ Informan yang akan diwawancarai adalah hakim dan panitera di Pengadilan Agama Bukittinggi. (2) Observasi merupakan pengumpulan data yang dilaksanakan melalui pengamatan langsung di lapangan yang ada kaitannya dengan masalah yang diteliti. Observasi dilakukan dengan mengamati secara langsung proses sidang ikrar talak di Pengadilan Agama Bukittinggi, dan mencatat seluruh hasil pengamatan. (3) Studi dokumentasi, dilakukan dengan cara mempelajari peraturan perundangundangan, laporan-laporan, termasuk arsip-arsip seperti pengumuman, instruksi dan sebagainya yang diperlukan oleh peneliti untuk menunjang penelitian ini. Disamping itu peneliti juga menyeleksi bahan-bahan pustaka, bukubuku ilmiah dan jurnal yang ada hubungannya dengan penelitian ini.

Data yang telah terkumpul dari hasil wawancara, observasi dan studi dokumentasi, selanjutnya akan diolah (data processing). Pada pengolahan data, pertama-tama dilakukan pemeriksaan data yang terkumpul, agar kelengkapan dan kesempurnaan informasi dapat terjamin. Setelah itu, data dicatat secara sistematis dan konsisten. Data yang telah disusun secara sistematis, selanjutnya dianalisis secara kualitatif dengan menggunakan pendekatan deskriptif analitis. Dari kegiatan analisis data, dapat diketahui seara deskriptif tentang objek penelitian yaitu tentang pelaksanaan sidang ikrar talak di Pengadilan Agama Bukittinggi.

\section{KONSEP TALAK DALAM FIQH}

Talak adalah suatu kata yang diambil dari bahasa Arab yang berasal dari kata" Thalaqa" yang berarti:

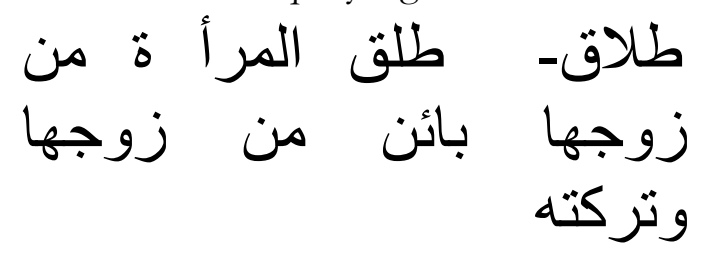

Artinya: "Perempuan berpisah dari suaminya. Maksudnya perempuan menjadi benar-benar cerai (bain) dari suaminya dan meninggalkannya. ${ }^{6}$

Pengertian ini menyangkut melepaskan ikatan perjanjian antara seseorang dengan orang lain, baik menurut kenyataan ataupun yang tidak nyata. Selanjutnya Abdurrahman AlJaziri mengemukakan bahwa, talak ialah:

${ }^{6}$ Abu Luis Al Ma'lufy, al-Munjid fi al-Lughab (Beirut: Dar al Masyraiq Katholikiyah, 1977), 470. 


\section{ازالة النكاح او نقصان حلة بلفظ

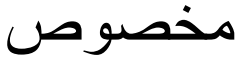

Artinya: "Talak ialah menghilangkan ikatan perkawinan atau mengurangi pelepasan ikatan dengan menggunakan kata-kata tertentu."

Lebih lanjut Abdurrahman alJaziri menjelaskan bahwa yang dimaksud dengan menghilangkan ikatan pernikahan ialah mengangkat ikatan pernikahan itu sehingga tidak lagi isteri itu halal digauli oleh suaminya ( dalam hal ini kalau terjadi talak tiga). ${ }^{8}$ Sedangkan yang dimaksud dengan mengurangi pelepasan ikatan perkawinan ialah berkurangnya hak talak bagi suami (dalam hal ini kalau terjadi talak raj'i). Kalau suami mentalak isterinya dengan talak satu, maka masih ada dua talak lagi. Kalau talak dua, maka tinggal satu talak lagi. Kalau sudah talaktiga, maka hak talaknya menjadi habis.

Definisi di atas, di samping mengutamakan lafaz yang dipergunakan, juga menjelaskan akibat yang ditimbulkan oleh ucapan talak. Artinya bahwa talak merupakan suatu perbuatan yang dilaksanakan dengan sengaja dengan maksud menghapuskan dan menghilangkan hubungan perkawinan. Hal ini juga dicantumkan dalam hukum di Indonesia yang menjelaskan tentang talak, seperti dalam Kompilasi Hukum Islam (KHI) pada Pasal 117 yang menjelaskan pengertian talak. Talak adalah ikrar suami dihadapan sidang Pengadilan Agama yang menjadi salah

7 Abdurrahman al-Jaziri, al-Fiqh Ala Mazabibul Arba'ab (Mesir: al-Maktabah al-Tijaniyah alKubra,1969), Juz IV, 278.

8 Ibid., 278.

9 Abdurrahman al-Jaziri, al-Fiqh Ala Mazabibul Arba'ah, 280. satu sebab putusnya perkawinan, sebagaimana dimaksud dalam Pasal 129, $130,131$.

Talak dalam syariat Islam merupakan jalan terakhir yang ditempuh oleh pasangan suami isteri dalam mengarungi bahtera rumah tangga ketika ketidakharmonisan dan kasih sayang yang tidak ada lagi antar pasangan, maka ajaran Islam memberikan solusi yang terbaik yaitu talak. ${ }^{11}$ Dalam Al-Qur'an tidak ditemukan aturan tentang perintah atau larangan melakukan talak, sehingga dapat dikatakan bahwa hukumnya mubah. Namun talak termasuk perbuatan yang tidak disenangi, sehingga dapat diartikan hukumnya makruh.

Ketidaksenangan itu tergambar dalam hadits Nabi dari Ibnu Umar menurut riwayat Abu Daud, Ibnu Majah dan disahkan oleh Hakim, sabda Nabi:

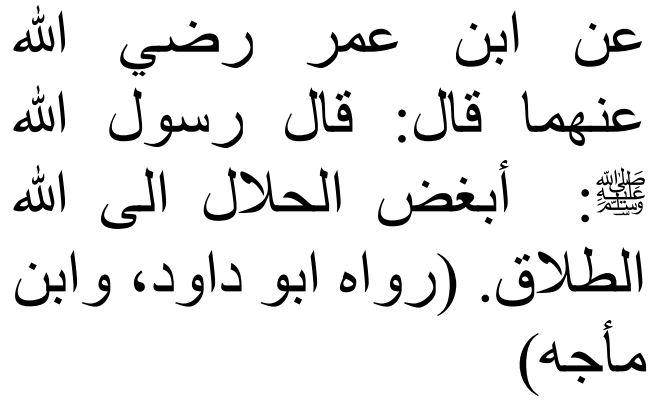

Artinya: Dari Ibnu Umar Radhiyallabu Anbuma berkata, Rasulullah Shalallabu Alaibi wa Sallam bersabda, "Perkara balal yang paling dibenci oleh Allah adalah Talak." (HR. Abu Dawud dan

10 Abdul Manan, M. Fauzan, Pokok-Pokok Hukum Perdata Wewenang Peradilan Agama (Jakarta: Raja Grafindo Persada, 2002), 28.

11 Nurdin Bakri dan Antoni, "Talak di Luar Pengadilan Menurut Fatwa Mpu Aceh No. 2 tahun 2015 tentang Talak." Samarah: Jurnal Hukum Keluarga dan Hukum Islam 1, no. 1 (2017): 53

12 Makmun Syar'i, "Reformulasi Hukum Talak Di Luar Pengadilan." Mazabib: Jurnal Pemikiran Hukum Islam 14, no.1 (2015): 69 


$$
\text { Ibnu Majah) })^{13}
$$

Dalam hukum positif Indonesia, talak diartikan dengan perceraian. Istilah perceraian secara yuridis berarti putusnya perkawinan, yang mengakibatkan putusnya hubungan sebagai suami isteri. Istilah perceraian terdapat dalam pasal 38 UU No 1 Tahun 1974 yang memuat ketentuan yang menyatakan bahwa "Perkawinan dapat putus karena kematian, perceraian dan atas putusan Pengadilan". Istilah perceraian menurut UU No. 1 Tahun 1974 sebagai aturan hukum positif tentang perceraian menunjukkan adanya: ${ }^{14}$

1) Tindakan hukum yang dapat dilakukan oleh suami atau isteri untuk memutus hubungan perkawinan di antara mereka;

2) Peristiwa hukum yang memutuskan hubungan suami dan isteri, yaitu kematian suami atau isteri yang bersangkutan, yang merupakan ketentuan yang pasti dan langsung ditetapkan oleh Tuhan yang Maha Kuasa;

3) Putusan hukum yang dinyatakan oleh Pengadilan yang berakibat hukum putusnya hubungan perkawinan antara suami dan isteri.

Selanjutnya dalam pasal 39 ayat 1 dijelaskan bahwa, "Perceraian hanya dapat dilakukan didepan sidang Pengadilan setelah Pengadilan yang bersangkutan berusaha dan tidak berhasil mendamaikan kedua belah pihak." Dalam hal ini perceraian harus melalui persidangan. Pengadilan

13 Muhammad bin Ismail al-Kahlani, Subulus Salam Syarah Bulughul Maram (Jakarta Timur: Darus Sunnah Press), Jilid III, 12.

${ }^{14}$ Muhammad Syaifuddin, Hukum Perceraian (Jakarta Timur: Sinar Grafika, 2013), 15. mengadakan upaya perdamaian dengan memerintahkan kepada pihak yang akan bercerai untuk memikirkan segala kemudharatan yang akan terjadi jika perceraian itu terjadi. ${ }^{15}$

Perkara perceraian di Pengadilan Agama dibedakan atas cerai talak dan cerai gugat. Cerai talak adalah perkara perceraian yang inisiatif untuk mengajukan perkaranya ke pengadilan berasal dari pihak suami. Dalam hal ini dapat dikatakan bahwa keinginan untuk bercerai datang dari suami. Sebaliknya, apabila inisiatif untuk mengajukan perkara perceraian tersebut datang dari pihak isteri, maka hal ini disebut cerai gugat. Hal ini sebagaimana diatur dalam Undang-undang Perkawinan Indonesia.

Perceraian menurut hukum Islam yang telah dicantumkan dalam pasal 38 dan 39 UU Perkawinan Nomor 1 Tahun 1974 dan telah dijabarkan dalam PP Nomor 9 Tahun 1975, mencakup antara lain:

a.Perceraian dalam pengertian cerai talak, yaitu perceraian yang diajukan permohonan cerainya oleh dan atas inisiatif suami kepada Pengadilan Agama, yang dianggap terjadi dan berlaku berserta segala akibat hukumnya sejak saat perceraian itu dinyatakan (diikrarkan) di depan sidang Pengadilan Agama. ${ }^{16}$

b. Perceraian dalam pengertian cerai gugat, yaitu perceraian yang diajukan gugatan cerainya oleh dan atas inisiatif isteri kepada Pengadilan Agama, yang dianggap terjadi dan berlaku beserta segala akibat hukumnya sejak jatuhnya putusan

15 Makinudin, “ Ikrar Talak Di depan Sidang Pengadilan Agama (Analisis Penerapan Kaidah Tafsir 'Amr dan 'Am)." Al-Hukama: The Indonesian Journal of Islamic Family Law 1, no.1 (2011): 76.

${ }^{16}$ Muhammad Syaifuddin, Hukum Perceraian, 
pengadilan Agama yang telah mempunyai kekuatan hukum tetap. ${ }^{17}$

Sidang ikrar talak hanya berlaku untuk perkara cerai talak. Sidang ini berkaitan dengan tahap-tahap pelaksanaan dalam proses hukum cerai talak yang terdiri dari beberapa tahapan, yaitu:

1. Pengajuan Permohonan Cerai Talak.

2. Pemeriksaan dan Perdamaian .

3. Proses Pembuktian.

4. Putusan Permohonan cerai talak.

5. Sidang Ikrar Talak.

6. Penetapan Ikrar Talak.

7. Akta Cerai.

Al-Haddad mengemukakan sedikitnya empat alasan pentingnya ikrar talak didepan pengadilan, yaitu:

a.Kehadiran pengadilan adalah untuk meluruskan segala tindakan yang melenceng untuk disesuaikan dengan ajaran Islam. Dalam kasus talak seorang suami sebelum menjatuhkan talak harus berpikir mendalam tentang dampak yang ditimbulkan oleh keputusannya itu sehingga ia lebih berhati-hati dan rasional.

b. Melalui proses pengadilan diharapkan penggunaan hak talak dilakukan secara benar dan diterapkan dalam kondisi darurat.

c.Pengadilan sebenarnya berfungsi sebagai Hakam seperti yang dianjurkan oleh syari'at Islam.

d. Pengadilan diharapkan dapat berperan menjamin hak-hak masingmasing pihak sebagai akibat dari perceraian, misalnya jaminan ganti rugi dalam talak dan $m u t^{\prime} a{ }^{18}{ }^{18}$
Penerapan aturan hukum tersebut diharapkan dapat memperkecil angka perceraian antara suami dan isteri, sebab pada hakikatnya pernikahan adalah sesuatu yang harus dipertahankan hingga hanya kematian yang memisahkan. ${ }^{19}$

\section{PELAKSANAAN SIDANG IKRAR TALAK DI PENGADILAN AGAMA BUKITTINGGI}

Sidang ikrar talak merupakan tahap akhir dari proses persidangan dalam perkara cerai talak. Sebagaimana diketahui bahwa perkara perceraian di Pengadilan Agama dibedakan atas cerai talak dan cerai gugat, demikian pula halnya di Pengadilan Agama Bukittinggi. Perkara perceraian merupakan perkara yang dominan diselesaikan oleh Pengadilan Agama Bukittinggi. Hal ini dapat dilihat pada tabel berikut.

Tabel 1: Jumlah Perkara pada tahun 2014

\begin{tabular}{|c|c|c|}
\hline NO & Jenis Perkara & Jumlah \\
\hline 1 & Cerai Talak & 169 \\
\hline 2 & Cerai Gugat & 393 \\
\hline 3 & Perkara Lain & 136 \\
\hline & Jumlah & 698 \\
\hline
\end{tabular}

Tabel 2: Jumlah Perkara pada tahun 2015

\begin{tabular}{|c|c|c|}
\hline NO & Jenis Perkara & Jumlah \\
\hline 1 & Cerai Talak & 188 \\
\hline 2 & Cerai Gugat & 400 \\
\hline 3 & Perkara Lain & 143 \\
\hline & Jumlah & 731 \\
\hline
\end{tabular}

19 Fikri, Saidah, Aris dan Wahidin, “ Contextualization of Divorce Through Fiqh and National Law In Indonesia." Al-Ulum 19, no. 1 (2019): 155. 
Tabel 3: Jumlah Perkara pada tahun 2016

\begin{tabular}{|c|c|c|}
\hline NO & Jenis Perkara & Jumlah \\
\hline 1 & Cerai Talak & 191 \\
\hline 2 & Cerai Gugat & 476 \\
\hline 3 & Perkara Lain & 219 \\
\hline & Jumlah & 886 \\
\hline
\end{tabular}

Berdasarkan data di atas, ada beberapa hal yang dapat dijelaskan:

1. Jumlah perkara yang masuk ke Pengadilan Agama Bukittinggi, mengalami peningkatan dari tahun ke tahun. Dari tahun 2014 hingga tahun 2015, mengalami kenaikan kebih kurang 4,7 \%, sedangkan tahun 2015 hingga tahun 2016, kenaikannya sekitar $21 \%$.

2. Perkara-perkara di Pengadilan Agama didominasi oleh perkara perceraian. Lebih kurang $70 \%$ dari perkara yang masuk adalah tentang perceraian.

3. Sebagian besar kasus perceraian yang diputuskan oleh Pengadilan Agama Bukittinggi adalah kasus cerai gugat, yaitu perceraian yang inisiatif untuk mengajukan perkaranya ke pengadilan berasal dari pihak isteri. Jumlah perkara cerai gugat dua kali lebih banyak dari cerai talak. "Kasus cerai gugat ini terjadi terutama disebabkan persoalan ekonomi seperti; ketidakmampuan pihak suami dalam memenuhi kebutuhan keluarga" ${ }^{20} \mathrm{Hal}$ ini merupakan penyebab timbulnya perselisihan dan pertengkaran dalam keluarga. Jumlah kasus cerai talak jauh lebih sedikit dari cerai gugat. Cerai talak

20 Elzawarti, Panitera Muda Hukum Pengadilan Agama Bukittinggi, wawancara, Senin, tanggal 16 Oktober 2017. yaitu perceraian yang inisiatif untuk mengajukan perkaranya ke Pengadilan Agama berasal dari suami.

Sidang ikrar talak hanya berlaku untuk perkara cerai talak. Pelaksanakan sidang ikrar talak di Pengadilan Agama Bukittinggi berkaitan dengan putusan terhadap permohonan cerai talak yang sudah berkekuatan hukum tetap. Majelis Hakim menjatuhkan putusan setelah melaksanakan persidangan sesuai dengan proses dan prosedur yang diatur dalam perundang-undangan yang berlaku. ${ }^{21}$ Berkaitan dengan proses persidangan ini, maka pelaksanaan sidang ikrar talak dapat dijelaskan sebagai berikut:

Sidang ikrar talak berhubungan dengan perkara cerai talak yang telah diputuskan oleh Pengadilan Agama, dan telah mempunyai kekuatan hukum tetap. Proses persidangan tersebut adakalanya dihadiri oleh isteri (termohon), dan ada pula yang tidak dihadiri. Dalam hal tidak dihadiri oleh termohon, maka perkara tersebut akan diputuskan secara verstek (tanpa hadirnya termohon).

Di Pengadilan Agama Bukittinggi, dalam perkara cerai talak, putusan verstek diterapkan setelah Majelis Hakim memberikan kesempatan sekali lagi kepada termohon untuk hadir menghadap persidangan. Artinya, apabila termohon tidak hadir pada sidang pertama, maka Majelis Hakim akan menunda sidang, guna memanggil termohon untuk menghadiri sidang kedua. Jika termohon tetap tidak hadir setelah dipanggil kembali untuk menghadap persidangan, maka pada sidang kedua tersebut akan dilaksanakan

${ }^{21}$ Mohamad Barmawi, "Ikrar Talak Pengadilan Agama (Analisis Atas Istinbath Hukum Pengadilan Agama tentang Sahnya Perceraian)." Jurnal Qolamuna 1, no, 2 (2016): 196. 
pemeriksaan pokok perkara. Jika pada sidang kedua ini pemohon siap dengan alat-alat bukti, maka akan dilakukan sidang dengan agenda pembuktian, jika tidak sidang akan ditunda untuk tahap pembuktian tersebut. ${ }^{22}$

Sesuai dengan ketentuan Pasal 125 HIR/149 RBg di atas, sebenarnya, Majelis Hakim bisa saja menjatuhkan putusan verstek pada sidang pertama tanpa melakukan pemeriksaan. Namun Hakim juga boleh menunda sidang dengan tujuan memberikan kesempatan kepada termohon untuk membela haknya dalam rangka mewujudkan kesetaraan dan keadilan di depan hukum. Artinya, penerapan putusan verstek di Pengadilan Agama Bukittinggi didasarkan pada pertimbangan kepantasan dan kepatutan, serta memberikan toleransi kepada termohon untuk hadir ke persidangan.

Salah satu kasus cerai talak yang diputuskan secara verstek oleh Majelis Hakim Pengadilan Agama Bukittinggi adalah Kasus Cerai talak Nomor 0403/Pdt.G/2017/PA.Bkt. Kasus ini sudah diputuskan oleh Majelis Hakim Pengadilan Agama Bukittinggi secara verstek pada tanggal 28 Agustus 2017. Berdasarkan hasil pengamatan yang telah dilakukan terhadap pelaksanaan sidang ikrar talak di Pengadilan Agama Bukittinggi, peneliti dapat menjelaskan sebagai berikut;

a. Sidang ikrar talak tidak dihadiri oleh termohon (isteri), dan perkaranya telah diputuskan sebelumnya secara verstek.

b. Setelah Hakim Ketua membuka sidang, kepada pemohon ditanyakan tentang keputusannya

22 Martias, Hakim Pengadilan Agama Bukittinggi, wawancara, Senin, tanggal 16 Oktober 2017. untuk menjatuhkan ikrar talak terhadap termohon. Artinya apakah pemohon tetap dengan keputusannya untuk mentalak isterinya. Dalam hal ini pemohon menyatakan bahwa dia tetap dengan keputusannya untuk menjatuhkan talak kepada isterinya. Pertanyaan ini diajukan oleh hakim dengan tujuan untuk masih memberikan kesempatan berpikir kepada pemohon.

c. Hakim juga menanyakan kepada pemohon, apakah ada usaha-usaha untuk berdamai dengan termohon. Menurut pemohon, tidak ada upaya dan juga tidak ada lagi keinginan untuk berdamai dengan termohon. Hal ini menunjukkan bahwa dalam setiap persidangan, hakim senantiasa berusaha untuk mendamaikan para pihak yang berperkara.

d. Berdasarkan pernyataan pemohon tentang kesiapannya untuk mengucapkan ikrar talak, hakim menanyakan kepada pemohon, apakah bisa mengucapkan sendiri ikrar talak tersebut. Oleh karena pemohon tidak bisa mengucapkan sendiri ikrar talak tersebut, maka hakim ketua membimbing pemohon untuk mengucapkan ikrar talak. Bunyi ikrar talak tersebut adalah: "Bismillaahirrahmaanirrahiim, pada hari ini ..., tanggal ..., Saya ...(nama lengkap suami)..., dengan ini menjatuhkan talak satu raj i kepada isteri saya yang bernama ...(nama lengkap isteri)...

e. Setelah pemohon mengucapkan ikrar talak, maka hakim ketua membacakan penetapan ikrar talak, dan terhadap penetapan 
ikrar talak ini tidak dapat lagi diajukan upaya hukum banding. Hal ini diatur dalam Pasal 71 ayat (2) UU Peradilan Agama yang menyatakan bahwa, hakim membuat penetapan yang isinya menyatakan bahwa perkawinan putus sejak ikrar talak diucapkan, dan penetapan tersebut tidak dapat dimintakan banding atau kasasi.

Dalam hal isteri (termohon) tidak hadir dalam sidang ikrar talak, sidang akan tetap dilanjutkan sesuai agenda yang telah ditentukan tanpa hadirnya termohon. Hadir atau tidaknya pihak termohon tanpa alasan yang sah menurut hukum, tidak akan menjadi penghalang bagi kelangsungan sidang ikrar talak. Pada hari yang ditentukan tersebut tetap akan dilaksanakan ikrar talak oleh suami, sebab kedua pihak telah dipanggil secara sah dan patut. Setelah Pengadilan Agama memberikan izin kepada pemohon untuk menjatuhkan talak, hak talak sepenuhnya menjadi milik pemohon sebab pada dasarnya hakim bersifat pasif.

Dalam sidang Ikrar Talak, Majelis Hakim akan tetap berusaha mendamaikan/menasehati pemohon, akan tetapi jika pemohon tetap akan menggunakan hak talaknya, maka dilaksanakanlah ikrar talak tersebut. Jika suami meminta kepada Majelis Hakim untuk mengundur sidang dengan alasan akan memikirkan kembali, maka Majelis Hakim dapat melakukan penundaan sidang sebab jangka waktu pelaksanaan ikrar talak setelah putusan berkekuatan hukum tetap adalah enam bulan.

Keadaan suci atau tidaknya isteri tidak menjadi pertimbangan hukum bagi hakim dalam pelaksanaan sidang ikrar talak di Pengadilan. Dalam hal isteri (termohon) tidak hadir dalam sidang ikrar talak, maka isteri dianggap dalam keadaan suci, apalagi jika keadaan isteri sebagai termohon tidak diketahui. Oleh karena itu, ketidakhadiran isteri (termohon) tidak menjadi penghalang untuk sidang ikrar talak.

Sidang ikrar talak adakalanya dihadiri oleh isteri (termohon). Salah satu kasus cerai talak yang sidang ikrar talaknya dihadiri oleh isteri (termohon) adalah Perkara No. 0146/Pdt.G/2017/PA.Bkt. Dalam hal ini pelaksanaan sidang ikrar talak dapat dijelaskan sebagai berikut:

a. Pada tahap pertama, hakim ketua membuka sidang ikrar talak yang dinyatakan terbuka untuk umum.

b. Selanjutnya hakim ketua menanyakan kepada para pihak (pemohon dan termohon), apakah ada upaya damai dari masingmasing pihak, sejak putusan dibacakan sampai sidang ikrar talak. Apabila ada peluang untuk berdamai dari para pihak, maka hakim akan menunda sidang ikrar talak, guna memberikan kesempatan untuk berdamai. Jika tidak, proses sidang ikrar talak dilanjutkan.

c. Dalam kasus ini, ada tuntutan isteri yang harus dibayarkan oleh suami sesuai dengan yang telah ditetapkan oleh Majelis Hakim ketika proses persidangan perceraian. Dalam hal ini, sebelum pengucapan ikrar talak, hakim menanyakan kepada suami (pemohon), apakah tuntutan isteri (termohon) yang telah diputuskan sudah ada. Apabila sudah disediakan, maka hakim meminta kepada pemohon untuk menyerahkannya kepada Panitera. 
Setelah dihitung di hadapan hakim, maka Panitera menyerahkan kepada isteri (termohon).

Dalam hal suami (pemohon) tetap pada keputusannya untuk menjatuhkan talak kepada isterinya, maka hakim akan menanyakan kepada pemohon apakah bisa mengucapkan sendiri ikrar talak tersebut. Jika tidak, maka hakim akan membimbing pengucapan ikrar talak sebagaimana telah dijelaskan di atas. Pada umumnya hakim selalu membimbing pemohon untuk mengucapkan ikrar talak.

Pengucapan ikrar talak dapat pula dikuasakan kepada seorang wakil/kuasa dengan kuasa istimewa untuk pengucapan ikrar talak. Hal ini sesuai dengan Pasal 70 ayat (5) UU No 7 Tahun 1989 tentang Peradilan Agama jo KHI, yang menyatakan bahwa, "Jika isteri telah mendapat panggilan secara sah atau patut, tetapi tidak datang menghadap sendiri atau tidak mengirim wakilnya, maka suami atau wakilnya dapat mengucapkan ikrar talak tanpa hadirnya isteri atau wakilnya".

\section{HIKMAH TENGGANG WAKTU UNTUK IKRAR TALAK}

Tenggang waktu untuk mengucapkan ikrar talak ditetapkan dalam Pasal 70 ayat (6) UU Peradilan Agama yang berbunyi, "Jika suami dalam tenggang waktu 6 (enam) bulan sejak ditetapkan hari sidang penyaksian ikrar talak, tidak datang menghadap sendiri atau tidak mengirim wakilnya, meskipun telah mendapat panggilan secara sah/patut, maka gugurlah kekuatan penetapan tersebut dan perceraian tidak dapat diajukan lagi berdasarkan alasan yang sama". Ketentuan ini menegaskan bahwa, ikrar talah harus diucapkan oleh suami (pemohon) dalam tenggang waktu paling lama 6 (enam) bulan sejak Penetapan Hari Sidang penyaksian ikrar talak. Apabila dalam tenggang waktu yang telah ditetapkan ini, suami (pemohon) tidak datang untuk mengikrarkan talaknya, maka penetapan perceraiannya gugur.

Undang-undang Peradilan Agama, tidak menjelaskan latar belakang dan pertimbangan dalam menetapkan tenggang waktu enam bulan untuk ikrar talak. Demikian pula dalam perundangundangan yang lain seperti Kompilasi Hukum Islam, juga tidak ditemukan penjelasan tentang hal ini. Di dalam pelaksanaan sidang ikrar talak dengan tenggang waktu 6 bulan tersebut, dapat ditarik beberapa hikmah dari penetapan tenggang waktu tersebut.

Beberapa hikmah dari penetapan tenggang waktu 6 (enam) bulan untuk sidang penyaksian ikrar talak adalah:

1. Memberikan kesempatan kepada suami (pemohon) untuk mengikrarkan talaknya di hadapan sidang pengadilan. Artinya suami masih diberi kesempatan memikirkan kembali untuk menceraikan isterinya. ${ }^{23}$ Para pihak masih mempunyai peluang dan diberi kesempatan untuk memperbaiki hubungan mereka, serta membatalkan keinginan untuk bercerai. Dalam hal ini, upaya damai harus selalu menjadi prioritas utama bagi hakim dalam pelaksanaan tugasnya pada kasus perceraian. Di samping itu perdamaian merupakan asas pokok dalam Hukum Acara Peradilan Agama.

23 Martias, Hakim Pengadilan Agama Bukittinggi, Wawancara, Senin,tanggal 23 Oktober 2017 
2. Memberi waktu kepada suami (pemohon) untuk memenuhi hakhak isteri yang dituntut di persidangan dan diputuskan oleh Majelis Hakim. Hak-hak ini seperti; nafkah iddah, uang mut'ah, nafkah anak, dan tuntutan-tuntutan yang lain. Kalau suami langsung mengikrarkan talaknya pada sidang tersebut, sedangkan tuntutan-tuntutan isteri belum dipenuhi, maka dikhawatirkan suami (pemohon) melalaikan atau tidak mau membayar hak-hak isteri. Hal ini merupakan pembelaan terhadap hak-hak perempuan (isteri). Namun demikian, adakalanya sidang ikrar talak tetap dilanjutkan dengan pengucapan ikrar talak oleh suami (pemohon), dengan perjanjian bahwa suami akan membayar hak-hak isteri setelah terjadi ikrar talak di luar pengadilan. Akan tetapi, hal ini tidak bisa menjamin bahwa suami akan menepati perjanjian tersebut. Hal ini sering terjadi, sehingga isteri yang sudah diceraikan meminta kepada pengadilan untuk mengeksekusi tuntutan yang tidak dibayarkan oleh bekas suami. ${ }^{24}$.

Dalam hal tuntutan isteri belum bisa dipenuhi oleh suami (pemohon), maka Hakim menunda sidang ikrar talak, untuk memberikan kesempatan bagi suami memenuhi tuntutan isteri. Pada dasarnya hal ini tidak diatur dalam undang-undang, melainkan ijtihad majelis hakim untuk membela hak-hak perempuan, kecuali jika keharusan

24 Elzawarti, Panitera Muda Hukum Pengadilan Agama Bukittinggi, Wawancara, Senin, taggal 23 Oktober 2017. pemenuhan hak-hak isteri tersebut dicantumkan dalam amar putusan ${ }^{25}$.

\section{PENUTUP}

Berdasarkan hasil penelitian tentang pelaksanaan sidang ikrar talak di Pengadilan Agama Bukittinggi, dapat ditarik kesimpulan bahwa pertama, pelaksanaan sidang ikrar talak di Pengadilan Agama Bukittinggi dilakukan setelah keputusan perkara cerai talak mempunyai kekuatan hukum tetap (inkracht), yaitu apabila terhadap putusan tersebut tidak ada lagi upaya hukum biasa. Tenggang waktu yang diberikan untuk melaksanakan ikrar talak di Persidangan setelah putusan Berkekuatan Hukum Tetap (BHT), adalah enam bulan sejak penetapan hari sidang ikrar talak. Kedua, hikmah dari penetapan tenggang waktu 6 (enam) bulan bagi suami untuk mengikrarkan talaknya adalah; untuk memberikan kesempatan berpikir kepada suami guna mengkaji ulang keputusan menceraikan isterinya. Begitu juga perlindungan terhadap hak-hak perempuan (isteri), dalam hal ini, suami diberi kesempatan dalam tenggang waktu tersebut, untuk memenuhi hak-hak isteri yang dituntut di persidangan dan diputuskan oleh ajelis hakim. Tujuan utama dari ketentuan tenggang waktu untuk ikrar talak adalah untuk mempersulit terjadinya perceraian dan kemaslahatan terhadap suami (pemohon) dan isteri (termohon)

Berdasarkan kesimpulan tentang pelaksanaan sidang ikrar talak di atas, saran dari peneliti adalah; pertama, sebaiknya sidang ikrar talak dihadiri oleh isteri, agar masing-masing pihak (suami

25 Martias, Hakim Pengadilan Agama Bukittinggi, Wawancara, Senin, tanggal 23 Oktober 2017. 
isteri) dapat memahami akibat hukum dari perceraian, terutama terkait kewajiban suami terhadap isteri yang ditalak, serta kewajiban terhadap anak. Oleh karena itu, diharapkan ada upaya dari pengadilan untuk menghadirkan isteri, kecuali dalam hal isteri memang tidak diketahui keberadaannya. Kedua, pemerintah melalui lembaga terkait perlu melakukan penyuluhan secara berkala kepada masyarakat, sehubungan dengan hak dan kewajiban yang timbul karena perceraian. Hal ini diharapkan dapat memberikan wawasan kepada masyarakat tentang tanggung jawab yang dipikul akibat perceraian. Ketiga, Sidang ikrar talak sebaiknya dilakukan setelah suami memenuhi semua tuntutan isteri di persidangan yang telah diputuskan oleh pengadilan. Hal ini dimaksudkan agar suami tidak melalaikan kewajibannya untuk membayarkan tuntutan isteri. Seandainya ikrar talak telah diucapkan sebelum suami memenuhi tuntutan isteri, dikhawatirkan suami akan ingkar janji.

\section{DAFTAR KEPUSTAKAAN}

Abustam, H. "Pelaksanaan Ikrar Talak di Hadapan Sidang Pengadilan Agama (Suatu Tinjauan Filsafat Hukum Islam)." Al-Risalah: Jurnal Hukum Keluarga Islam 2, no. 2 (2016): 161.

al-Ma'lufy, Abu Luis. al-Munjid fi al-Lughah. Beirut: Dar al Masyraiq, Katholikiyah, 1977.

al-Jaziri, Abdurrahman. al-Fiqh Ala Mazabibul Arba'ah, Juz IV. Mesir: al-Maktabah al-Tijaniyah alKubra, 1969.

al-Kahlani, Muhammad bin Ismail. Subulus Salam Syarah Bulughul Maram. Jakarta Timur: Darus Sunnah Press, 1926.

Asmara, Musda dan Reti Andira. "Urgensi Talak di Depan Sidang Pengadilan Perspektif Maslahah Mursalah." Al-Istinbath: Jurnal Hukum Islam 3, no.2 (2018): 208.

Bakri, Nurdin dan Antoni. " Talak di Luar Pengadilan Menurut Fatwa Mpu Aceh No. 2 tahun 2015 tentang Talak.” Samarah: Jurnal Hukum Keluarga dan Hukum Islam 1, no. 1 (2017): 53.

Barmawi, Mohamad. "Ikrar Talak Pengadilan Agama (Analisis Atas Istinbath Hukum Pengadilan Agama tentang Sahnya Perceraian).” Jurnal Qolamuna 1, no, 2 (2016): 196.

Fikri, Saidah, Aris dan Wahidin. "Contextualization of Divorce Through Fiqh and National Law In Indonesia." Al-Ulum 19, no. 1 (2019): 155.

Makinudin, "Ikrar Talak Di depan Sidang Pengadilan Agama (Analisis Penerapan Kaidah Tafsir 'Amr dan 'Am)." Al-Hukama: The Indonesian Journal of Islamic Family Law 1, no.1 (2011): 76.

Manan, Abdul dan M. Fauzan. Pokok-Pokok Hukum Perdata Wewenang Peradilan Agama. Jakarta: Raja Grafindo Persada, 2002.

Moleong, Lexy J. Metode Penelitian Kualitatif. Bandung: PT. Remaja Rosda Karya, 1997.

Nuruddin, Amiur. Hukum Perdata Islam di Indonesia. Jakarta: Kencana Prenada Media Group, 2006.

Syaifuddin, Muhammad. Hukum Perceraian. Jakarta Timur: Sinar Grafika, 2013.

Syar'i, Makmun. "Reformulasi Hukum Talak Di Luar Pengadilan." Mazabib: Jumal Pemikiran Hukum Islam 14, no.1 (2015): 69.

Informan

Elzawarti, Panitera Muda Hukum Pengadilan Agama Bukittinggi

Martias, Hakim Pengadilan Agama Bukittinggi 